\title{
Analisis Kemampuan Pemecahan Masalah Siswa dalam Menyelesaikan Soal Matematika Tipe Higher Order Thinking Skill (HOTS)
}

\section{Muhammad IIman Nafi'an ${ }^{1}$ dan Shimawaty Lutvy Pradani}

\author{
IInstitut Agama Islam Negeri Kediri \\ 2STKIP PGRI Tulungagung
}

Corresponding Author: ilman.indonesia@gmail.com¹ ; shimapradani01@ gmail.com²

DOI: http://dx.doi.org/10.15294/kreano.v10i2.15050

Received : July 18 2018; Accepted: November 30 2019; Published: December 42019

\begin{abstract}
Abstrak
Tujuan penelitian ini untuk mengetahui kemampuan memecahkan masalah siswa dalam mengerjakan soal tipe Higher Order Thinkimg Skills (HOTS). Kemampuan memecahkan masalah merupakan salah satu kemampuan yang penting untuk dikembangkan dan harus dimiliki oleh siswa. Dengan mengerjakan soal-soal Higher Order Thinking Skills, maka siswa akan mencapai level-level pada kemampuan matematika dari level yang terendah sampai level tertinggi. Tujuan dari penelitian ini adalah untuk mendiskripsikan pemecahan masalah siswa kelas XII IPA dalam menyelesaikan soal tipe Higher Order Thinking Skills berdasarkan langkah-langkah Polya. Penelitian ini menggunakan pendekatan kualitatif dengan jenis penelitian deskriptif. Pada penelitian ini peneliti juga menggunakan beberapa metode untuk mengumpulkan data antara lain: tes, wawancara dan dokumentasi. Hasil penelitian ini diperoleh kesimpulan bahwa siswa dalam memecahkan masalah menggunakan langkah Polya, dapat menuhi indikator menganalisis, menciptakan, dan mengevaluasi.
\end{abstract}

\begin{abstract}
The purpose of this study to determine the ability to solve student problems in working on the problem type Higher OrderThinkimg Skills (HOTS). Ability to solve problems is one of the important skills to be developed and must be owned by students. By working on the Higher Order Thinking Skills questions, students will reach the levels of mathematical ability from the lowest level to the highest level. The purpose of this research is to describe the problem solving of students of class XII IPA in solving the problem of Higher Order Thinking Skills type based on Polya steps. This research uses qualitative approach with descriptive research type. In this study the researchers also used several methods to collect data, among others: tests, interviews and documentation. The results of this study obtained the conclusion that students in solving problems using Polya step, can meet the indicators analyze, create, and evaluate.
\end{abstract}

Keywords: HOTS, mathematical problem solving, polya

\section{PENDAHULUAN}

Matematika merupakan mata pelajaran wajib pada setiap jenjang pendidikan di Indonesia, mulai dari sekolah dasar hingga ke perguruan tinggi. Peran pendidikan di sekolah yang terdapat dalam kurikulum berfokus untuk mengembangkan sumber daya manusia (SDM) yang meliputi kognitif, afektif dan psikomotor. Salah satu sumber daya pengetahuan dan keterampilan yaitu keterampilan berpikir tingkat tinggi (HigherOrder Thingking Skills), sehingga harus ditingkatkan dan dikembangkan (Magdalena, 2016; Tanujaya, 2016). Oleh karena itu, salah satu indikasi keberhasilan peningkatan SDM dalam bidang pendidikan adalah siswa memiliki keteram- 
pilan tingkat tinggi yang baik, karena tujuan utama pembelajaran pada abad ke 21 adalah untuk mengembangkan dan meningkatkan HOTS siswa (Arifin dan Retnawati, 2015).

Khususnya dalam pembelajaran matematika, HOTS merupakan salah satu prioritas keterampilan yang dikembangkan. Magdalena (2016) menyatakan bahwa matematika perlu diberikan kepada semua peserta didik mulai dari sekolah dasar untuk membekali peserta didik dengan kemampuan perpikir logis, analitis, sistematis, kritis, kreatif serta kemampuan pemecahan masalah dan kerja sama. Salah satu tujuan pembelajaran matematika di sekolah adalah memecahkan masalah yang meliputi kemampuan memahami masalah, merancang model matematika, menyelesaikan model, dan menafsirkan solusi yang diperoleh (Delyana, 2015).

Pemecahan masalah (Problem Solving) dan matematika merupakan dua komponen yang tidak terpisahkan. Hal tersebut terjadi karena pemecahan masalah (Problem Solving) merupakan aktivitas yang penting dalam pembelajaran matematika (Muliawati, 2016). Sejalan dengan National Council of Teaching Mathematiscs (2000) dan kurikulum 2013 yang menetapkan pemecahan masalah menjadi salah satu standar proses dan kompetensi yang harus dimiliki siswa. Berdasarkan hal tersebut, berarti kemampuan memecahkan masalah merupakan salah satu kemampuan yang penting untuk dikembangkan dan harus dimiliki oleh siswa.

Salah satu langkah yang digunakan dalam pemecahan masalah adalah tahapan yang disusun oleh Polya (1997) yaitu (1) memahami masalah, (2) membuat rencana pemecahan masalah, (3) menyelesaikan rencana masalah, dan (4) memeriksa kembali hasil yang diperoleh. Langkah-langkah dalam proses pemecahan masalah yang dikemukan Polya cukup sederhana, aktivitas-aktivitas pada setiap langkah cukup jelas dan langkah-langkah tersebut telah lazim digunakan dalam memecahkan masalah matematika. Dengan mengikuti keempat langkah tersebut, harapannya siswa akan terbantu dalam memetakan proses berpikirnya, memandang masalah berdasarkan pengetahuan yang dimilikinya, sehingga ia akan mampu menyelesaikan masalah yang diberikan dengan baik (Safrida et al, 2015).

Berdasarkan latar belakang masalah diatas, masalah penelitian ini difokuskan pada kemampuan pemecahan masalah matematika siswa dalam menyelesaikan soal matematika tipe Higher Order Thinking Skill (HOTS) pada Kurikulum 2013. Tujuan penelitian adalah untuk mendeskripsikan kemampuan pemecahan masalah matematika siswa dalam menyelesaikan soal matematika tipe Higher Order Thinking Skill (HOTS) pada Kurikulum 2013.

\section{METODE}

Penelitian ini ditinjau dari jenisnya termasuk penelitian kualitatif yang bersifat alami dan ditampilkan sebagaimana adanya tanpa unsur manipulasi atau perlakuan khusus terhadap objek penelitian. Dikatakan penelitian kualitatif karena penelitian ini berusaha mengungkap gejala secara menyeluruh sesuai dengan konteks melalui pengumpulan data berlatar alami (natural setting) dengan penelitian sebagai instrumen utama serta lebih mewujudkan proses dan makna dari sudut pandang subjek penelitian. Penelitian ini bersifat deskriptif dan cenderung menggunakan analisis dengan pendekatan induktif yang lebih menekankan proses dan makna. Penelitian tersebut bertujuan untuk mendiskripsikan kejadian atau peristiwa saat ini. Prosesnya dapat upaya mendiskripsikan, mencatat, dan menginterprestasikan kejadian-kejadian yang sekarang ini terjadi.

Penelitian ini akan dipilih subjek penelitian siswa kelas XII IPA SMA Negeri 1 Kalidawir. Penentuan subjek penelitian menggunakan tes yang akan di berikan pada 1 kelas yang berjumlah 27 siswa. Sedangkan cara pengambilan subjek penelitian dilakukan dengan menggunakan teknik Nonprobability Sampling. Prosedur penelitian yang dilakukan dalam penelitian ini meliputi, studi pendahuluan, pengembangan rancangan, pelaksanaan penelitian, penulisan laporan. Instrumen penelitian yang digunakan penelitian ini adalah peneliti sendiri sebagai instrumen utama dalam mengumpulkan data, dan dibantu dengan instrumen pendukung. Selain itu juga di lengkapi dengan soal matematika tipe Higher 
Order Thinking Skill (HOTS). Instrumen pendukung yang dimaksud meliputi: (1) Soal Tes Kemampuan Matematika (TKM). Tes Kemampuan Matematika merupakan tes yang bertujuan untuk mengetahui tingkat kemampuan matematika siswa dengan kriterianya berikut ini pada tabel 1; (2) Soal Tes Pemecahan Masalah Matematika (TPMM). Tes penyelesaian masalah matematika bertujuan untuk mengetahui pemecahan masalah pada siswa sesuai dengan langkah-langkah Polya; dan (3) Pedoman wawancara. Berupa pertanyaan untuk menggali informasi dari siswa dan guru mata pelajaran matematika terkait dengan kemampuan pemecahan masalah siswa.

Tabel 1. Kategori TKM berdasarkan skala Penilaian.

\begin{tabular}{cc}
\hline $\begin{array}{c}\text { Tingkat kemampuan } \\
\text { Matematika }\end{array}$ & Rentang Nilai \\
\hline Tinggi & $100 \mathrm{~N} \leq 80$ \\
Sedang & $80 \mathrm{~N} \leq 65$ \\
Rendah & $\mathrm{N} \leq 65$ \\
\hline
\end{tabular}

\section{HASIL DAN PEMBAHASAN}

\section{Langkah memahami masalah}

\section{Menganalisis}

Siswa SSA mampu menjelaskan soal dengan bahasanya sendiri dan mampu menjelaskan hubungan antara informasi yang ada dengan barisan dan deret yang tertulis, ia juga mampu mengelolanya dalam kalimat matematis. Maka siswa SSA memenuhi indikator memahami masalah pada poin menganalisis. Siswa YNO mampu menjelaskan soal dengan bahasanya sendiri, ia juga mampu mengelolanya dalam kalimat matematis, dan mampu mengetahui konsep matematika yang berhubungan dengan permasalahan. Maka siswa YNO memenuhi indikator memahami masalah pada poin menganalisis. Siswa WES mampu menjelaskan soal dengan bahasanya sendiri dan mampu menjelaskan hubungan antara informasi yang ada dengan barisan dan deret yang tertulis. Siswa WES juga mampu mengolah permasalahan kedalam kalimat matematis. Maka siswa WES memenuhi indikator memahami masalah pada poin menganalisis. Siswa WMP mampu menjelaskan soal dengan baik, ia juga mampu mengelolanya dalam kalimat matematis dan mampu men- getahui konsep matematika yang berhubungan. Maka siswa WMP memenuhi indikator memahami masalah pada poin menganalisis.

\section{Menciptakan}

Siswa SSA mampu menuliskan dan memberikan alasan informasi yang tersembunyi pada permasalahan. Maka siswa SSA memenuhi indikator memahami masalah pada poin menciptakan. Siswa YNO mampu menuliskan informasi yang tersebunyi dengan bahasanya sendiri dan dapat menjelaskan informasi tersembunyi yang ia dapat. Maka siswa YNO memenuhi indikator memahami masalah pada poin menciptakan. Siswa WES mampu menjelaskan informasi yang tidak tertulis pada soal dengan bahasanya sendiri. Maka siswa WES memenuhi indikator memahami masalah pada poin menciptakan. Siswa WMP mampu menemukan informasi yang tersembunyi dalam permasalahan tersebut. Maka siswa WMP memenuhi indikator memahami masalah pada poin menciptakan.

\section{Mengevaluasi}

Siswa SSA mampu meyakini kebenaran dari informasi yang telah ditulisnya. Maka siswa SSA memenuhi indikator memahami masalah pada poin mengevaluasi. Siswa YNO mampu menjelaskan tentang apa yang ia temukan dan meyakini kebenaran dari informasi yang telah ditulisnya. Maka siswa YNO memenuhi indikator memahami masalah pada poin mengevaluasi. Siswa WES mampu menjelaskan hubungan antar informasi dan memastikan bahwa semua penjelasannya telah diyakini kebenarannya. Maka siswa WES memenuhi indikator memahami masalah pada poin mengevaluasi. Siswa WMP mampu meyakini kebenaran dari informasi yang ditulisnya sudah benar. Maka siswa WMP memenuhi indikator memahami masalah pada poin mengevaluasi.

\section{Membuat rencana Menganalisis}

Siswa SSA mampu menghubungkan apa yang diketahui dan apa yang ditanyakan dalam permasalahan. Maka siswa SSA 
memenuhi indikator membuat rencana pada poin menganalisis.

SiswaYNO mampu menemukan hubungan antar apa yang diketahui dengan yang ditanyakan dalam soal dan dapat menjelaskan strategi yang akan digunakan dalam menyelesaikan solusi. Maka siswa YNO memenuhi indikator membuat rencana pada poin menganalisis.

Siswa WES mampu menjelaskan strategi yang akan digunakan dalam mengerjakan permasalahan untuk mendapatkan solusi yang dicari. Maka siswa WES memenuhi indikator membuat rencana pada poin menganalisis.

Siswa WMP mampu menjelaskan hubungan apa yang diketahui dengan strategi untuk mendapatkan solusi yang akan dicari. Maka siswa WMP memenuhi indikator menyusun rencana pada poin menganalisis.

\section{Menciptakan}

Siswa SSA mampu menentukan strategi yang tepat untuk mencari solusi yang akan diselesaikan. Maka siswa SSA memenuhi indikator membuat rencana pada poin menciptakan.

Siswa YNO mampu memilih strategi dengan tepat untuk mencari solusi yang akan diselesaikan secara benar dan efisien. Maka siswa YNO memenuhi indikator membuat rencana pada poin menciptakan.

Siswa WES mampu membuat rencana strategi yang digunakan agar solusi dapat ditemukan dengan benar. Maka siswa WES memenuhi indikator membuat rencana pada poin menciptakan.

Siswa WMP mampu menentukan strategi yang tepat untuk mencari solusi yang sesuai dengan harapannya. Maka siswa WMP memenuhi indikator membuat rencana pada poin menciptakan.

\section{Mengevaluasi}

Siswa SSA mampu menjelaskan konsep yang ada pada strategi yang dipilihnya untuk menyelessaikan solusi. Maka siswa SSA memenuhi indikator membuat rencana pada poin mengevaluasi.

Siswa YNO mampu memberikan penjelasan tentang strategi yang dipilihnnya dengan bahasanya sendiri. Maka siswa YNO memenuhi indikator membuat rencana pada poin mengevaluasi.

Siswa WES mampu menjelaskan konsep-konsep strategi yang digunakan untuk menyelesaikan solusi. Maka siswa WES memenuhi indikator membuat rencana pada poin mengevaluasi.

Siswa WMP mampu meyakini dan menjelaskan strategi yang dipilihnya untuk menyelesikan solusinya. Maka siswa WMP memenuhi indikator membuat rencana pada poin mengevaluasi.

\section{Menjalankan rencana Menganalisis}

Siswa SSA mampu menyelesaikan masalah sesuai dengan rencana yang dipilih. Maka siswa SSA memenuhi indikator menjalakan rencana pada poin menganalisis. Siswa YNO mampu menjalankan solusi sesuai dengan strategi yang telah ditentukan dalam rencananya. Maka siswa YNO memenuhi indikator menjalakan rencana pada poin menganalisis. Siswa WES mampu mengerjakan solusi berdasarkan strategi yang dipilihnya meskipun sedikit mengalami kesulitan. Maka siswa WES memenuhi indikator menjalakan rencana pada poin menganalisis. Siswa WMP mampu menyelesaikan masalah dengan strategi yang dipilihnya dalam langkah membuat rencana. Maka siswa WMP memenuhi indikator menjalakan rencana pada poin menganalisis.

\section{Menciptakan}

Siswa SSA mampu memastikan bahwa dalam proses menjalankan strateginya itu tepat dan benar. Maka siswa SSA memenuhi indikator menjalakan rencana pada poin menciptakan. Siswa YNO mampu meyakini bahwa ia berada dijalan yang benar dalam menjalankan stategi yang dipilihnya. Maka siswa YNO memenuhi indikator membuat rencana pada poin menciptakan. Siswa WES mampu meyakini bahwa ia dijalan yang sesuai dengan strategi yang dipilihnya. Maka siswa WES memenuhi indikator menjalakan rencana pada poin menciptakan.Siswa W MP belum mampu meyakini bahwa ia dijalan yang tepat, ia 
mengalami kesulitan dalam menjalankan rencananya. Maka siswa WMP tidak memenuhi indikator menjalakan rencana pada poin menciptakan.

\section{Mengevaluasi}

Siswa SSA meyakini bahwa strategi yang dijalankan sesuai dengan apa yang diharapkan. Maka siswa SSA memenuhi indikator menjalakan rencana pada poin mengevaluasi. Siswa YNO memberikan klarifikasi atas jawaban yang ia tulis bahwa sesuai harapan dan menemukan nilai akhir. Maka siswa YNO memenuhi indikator menjalakan rencana pada poin mengevaluasi. Siswa WES meyakini jawaban yang ia tulis sesuai strategi dan menemukan hasil akhir. Maka siswa WES memenuhi indikator menjalakan rencana pada poin mengevaluasi. Siswa WMP menyelesaikan strategi yang direncanakan meskipun mengalami kendala dalam proses pengerjaannya. Maka siswa WMP memenuhi indikator menjalakan rencana pada poin mengevaluasi.

\section{Memeriksa kembali Menganalisis}

Siswa SSA belum mampu menentukan langkah yang digunakan untuk melakukan uji solusi. Maka siswa SSA tidak memenuhi indikator memeriksa kembali pada poin menganalisis. Siswa YNO menuliskan uji solusi sesuai dengan rencana strategi yang dipilihnya. Maka siswa YNO memenuhi indikator memeriksa kembali pada poin menganalisis. Siswa WES hanya menuliskan strategi yang telah diselesaikan sebelumnya tanpa melakukan uji solusi kembali. Maka siswa WES tidak memenuhi indikator memeriksa kembali pada poin menganalisis. Siswa WMP mengerjakan kembali dengan strategi yang sama untuk menguji solusinya. Maka siswa WMP memenuhi indikator memeriksa kembali pada poin menganalisis.

\section{Menciptakan}

Siswa SSA tidak melakukan uji solusi dalam pengerjaannya. Maka siswa SSA tidak memenuhi indikator memeriksa kembali pada poin menciptakan. Siswa YNO melakukan uji solusi dengan pola beda yang berbeda dengan sebelumnya. Maka siswa YNO memenuhi indikator memeriksa kembali pada poin menciptakan. Siswa WES hanya terfokus pada hasil akhir tanpa melakukan uji solusi. Maka siswa WES tidak memenuhi indikator memeriksa kembali pada poin menciptakan. Siswa WMP melakukan uji solusi dengan benar. Maka siswa WMP memenuhi indikator memeriksa kembali pada poin menciptakan.

\section{Mengevaluasi}

Siswa SSA meyakini bahwa solusi pemecahan yang didapatkan sudah benar dan memberikan kesimpulan dari akhir pekerjaannya. Maka siswa SSA memenuhi indikator memeriksa kembali pada poin mengevaluasi. Siswa YNO memberikan penyelesaian lain dengan pola beda yang berbeda dan memberikan kesimpulan pada akhir penyelesaian. Maka siswa YNO memenuhi indikator memeriksa kembali pada poin mengevaluasi. Siswa WES menuliskan kesimpulan pada akhir penyelesaian dan meyakini bahwa nilai akhirnya sudah benar. Maka siswa WES memenuhi indikator memeriksa kembali pada poin mengevaluasi. Siswa WMP memberikan kesimpulan terhadap solusi yang ia kerjakan dan meyakini

Tabel 2. Pemecahan masalah dalam HOTS

\begin{tabular}{|c|c|c|c|c|c|c|c|c|c|c|c|c|}
\hline \multirow{3}{*}{ Inisial Siswa } & \multicolumn{12}{|c|}{ Tahapan Polya } \\
\hline & \multicolumn{3}{|c|}{$\begin{array}{c}\text { Memahami } \\
\text { Masalah }\end{array}$} & \multicolumn{3}{|c|}{$\begin{array}{c}\text { Membuat } \\
\text { Rencana }\end{array}$} & \multicolumn{3}{|c|}{$\begin{array}{c}\text { Menjalankan } \\
\text { Rencana }\end{array}$} & \multicolumn{3}{|c|}{$\begin{array}{c}\text { Memeriksa } \\
\text { Kembali }\end{array}$} \\
\hline & $\mathrm{A}$ & B & $\mathrm{C}$ & A & $\mathrm{B}$ & $\mathrm{C}$ & A & $\mathrm{B}$ & $\mathrm{C}$ & A & B & $\mathrm{C}$ \\
\hline SSA & $\mathrm{V}$ & $\mathrm{V}$ & $\mathrm{V}$ & $\mathrm{V}$ & $\mathrm{V}$ & $\mathrm{V}$ & V & $\mathrm{V}$ & $\mathrm{V}$ & & & \\
\hline YNO & $\mathrm{v}$ & v & v & V & $\mathrm{v}$ & V & V & v & v & V & V & v \\
\hline WES & $\mathrm{V}$ & V & $\mathrm{V}$ & $\mathrm{V}$ & v & V & 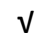 & v & $v$ & & & V \\
\hline WMP & V & $\mathrm{V}$ & $\mathrm{V}$ & $\mathrm{V}$ & $\mathrm{V}$ & V & V & & $\mathrm{V}$ & $\mathrm{V}$ & $\mathrm{V}$ & v \\
\hline
\end{tabular}


bahwa nilai akhirnya benar meskipun ada kesulitan dalam menghitung. Maka siswa WMP memenuhi indikator memeriksa kembali pada poin mengevaluasi.

Berdasarkan uraian di atas simpulan pemecahan masalah dalam menyelesaikan soal matematika tipe HOTS dapat disajikan dalam Tabel 2.

Kemampuan pemecahan masalah siswa dalam menyelesaikan soal tipe HOTS yang diberikan menunjukkan respon siswa untuk menghadapi serta bagaimana siswa mampu menggunakan seluruh pengetahuan yang dimilikinya untuk menyelesaikan masalah yang diberikan. Menurut Ayuningtyas (2013) kemampuan berfikir tingkat tinggi (HOTS) terdiri dari tiga elemen dasar, yakni menganalisis, menciptakan, dan mengevaluasi. Ketika ketiga elemen dasar telah ada pada diri siswa, maka siswa telah berpikir secara tingkat tinggi. Dari kemampuan berfikir tingkat tinggi yang dimiliki siswa, dapat diketahui kemampuan pemecahan masalah dalam mengerjakan soal matematika tipe HOTS yang berupa sebuah soal cerita dengan materi pokok pola barisan dan deret.

Berdasarkan pembahasan diatas, nampak hubungan antara pemecahan masalah dengan indikator HOTS. Hal ini telah dijelaskan oleh Ayuningtyas (2013) dengan mengerjakan soal-soal HOTS maka siswa akan mencapai level-level pada kemampuan matematika siswa, dari level yang terendah sampai level yang lebih tinggi yaitu menganalisis, menciptakan, dan mengevaluasi untuk menerapkan suatu prosedur atau cara untuk menyelesaikan masalah. Selama ini penyelesaian soal matematika tipe HOTS selalu dijadikan bahan untuk melatih kemampuan pemecahan masalah siswa untuk mehadapi soal yang lebih kompleks (Ayuningtyas, 2013; Utami, 2016; Ratnaningtyas, 2016).

Berdasarkan kajian dalam penelitian ini, ditemukan hubungan antara kedua hal tersebut. Siswa tergolong dalam siswa berkerampilan tingkat tinggi karena ketiga indikator HOTS telah ada dalam dirinya pada tahap pemecahan masalah model Polya yang petama dan kedua. Pada tahap ketiga yaitu menjalankan rencana, indikator HOTS telah ada dalam diri siswa. Sedangkan tahap memeriksa kem- bali, indikator HOTS tidak muncul secara keseluruhan, hanya indikator mengevaluasi saja yang dimiliki semua siswa berkemampuan tinggi, sedangkan menganalisis dan menciptakan hanya sebagian saja yang munculpada siswa. Hal tersebut sesuai dengan penjelasan Ayuningtyas (2013) dalam indikator menciptakan dan mengevaluasi, siswa memiliki kesadaran bahwa sebuah masalah akan terselesaikan jika ia mampu untuk membentuk suatu keseluruhan yang membuat hasil yang asli, seperti menyusun, merencanakan dan menghasilkan, namun kebanyakan siswa dalam tahap ini hanya menggunakan pengetahuan prosedural saja yaitu langkah penyelesaian yang diketahui atau pernah digunakan sebelumnya. Hal tersebut juga ditemukan dalam penelitian-penelitian lain, yang menyatakan bahwa cukup sulit untuk menemukan fakta pembelajaran terkait aktifitas siswa dalam memeriksa kembali jawaban dari permasalahan matematika (Widyastuti, 2015; Tisngati, 2015; Yohanes, 2016).

\section{SIMPULAN}

Berdasarkan hasil analisis data dan hasil penelitian yang telah diuraikan, maka dipeloleh simpulan sebagai berikut: (1) Kemampuan matematika yang dimiliki siswa dalam tahap memahami masalah dapat menuhi indikator menganalisis, menciptakan, dan mengevaluasi kerena siswa telah mampu memahami apa yang diketahui dan apa yang ditanyakan, serta apa syarat-syarat yang diketahui; (2) Kemampuan matematika yang dimiliki siswa dalam tahap membuat rencana dapat menuhi indikator menganalisis, menciptakan, dan mengevaluasi kerena siswa telah mampu menemukan hubungan antara data dengan yang ditanyakan/dibuktikan, dapat memilih teorema atau konsep yang telah dipelajari untuk dikombinasikan, sehingga dapat digunakan untuk menyelesaikan masalah; (3) Kemampuan matematika yang dimiliki siswa dalam tahap menjalankan rencana, dapat menuhi indikator menganalisis, dan mengevaluasi kerena siswa telah mampu menyelesaikan rencana sesuai dengan yang direncanakan. Ada beberapa siswa tidak memenuhi indikator menciptakan pada tahap menjalankan rencana karena mengalami kesulitan dalam menyelesaikan 
rencananya; (4) Kemampuan matematika yang dimiliki siswa dalam tahap memeriksa kembali, 50\% siswa dapat menuhi indikator menganalisis, menciptakan, dan mengevaluasi kerena siswa telah mampu mencocokkan jawaban yang diperoleh dengan permasalahan dan menuliskan kesimpulan terhadap apa yang ditanyakan. Sedangkan $50 \%$ siswa hanya mampu memenuhi indikator mengevaluasi karena tidak dapat mencocokkan jawaban yang diperoleh dengan permasalahan, dan hanya bisa memberikan kesimpulan dari solusinya.

\section{DAFTAR PUSTAKA}

Arifin, Z., \& Retnawati, H. (2015). Analisis Instrumen Pengukur Higher Order Thinking Skills (HOTS) Matematika Siswa SMA. In Makalah disampaikan pada Seminar Nasional Matematika dan Pendidikan Matematika UNY.

Arikunto, Suharsimi. 2010. Prosedur Penelitian Suatu Pendekatan Praktik. Jakarta: PT. Rineka Cipta

Ayuningtyas, N. (2013). Proses Penyelesaian soal Higher Order Thinking Skills Materi Aljabar Siswa SMP Ditinjau Berdasarkan Kemampuan Matematika siswa. Jurnal Pendidikan Matematika, 1(1), 48-58.

Delyana, H. (2015). Peningkatan Kemampuan Pemecahan Masalah Matematika Siswa Kelas VII Melalui Penerapan Pendekatan Open Ended. Lemma, Vol 2(1), 26-34.

Magdalena, W. (2016). Higher Order Thinking Skills (HOTS) Mathematics Untuk Mendukung Pembentukan Karakter siswa. Jurnal Ilmiah Pendidikan. 1(1), 451-456.

Muliawati, N. E. (2016). Proses Berpikir Lateral Siswa
Dalam Memecahkan Masalah, 2(1), 55-68.

Ratnaningtyas, Y. (2016). Kemampuan Berpikir Kritis Siswa SMP Kelas VIII dalam menyelesaikan Soal Higher Order Thinking ditinjau dari kemampuan matematika. MATHEdunesa, 5(1).

Safrida, L. N., Susanto, S., \& Kurniati, D. (2015). Analisis Proses Berpikir Siswa Dalam Pemecahan Masalah Terbuka Berbasis Polya Sub Pokok Bahasan Tabung Kelas IX SMP Negeri 7 Jember. KadikmA, 6(1).

Suryapuspitarini, B. K. (2018). Analisis Soal-Soal Matematika Tipe Higher Order Thinking Skill ( HOTS ) pada Kurikulum 2013 untuk Mendukung Kemampuan Literasi Siswa, 1, 876-884.

Tanujaya, B. (2016). Development of an Instrument to Measure Higher Order Thinking Skills in Senior High School Mathematics Instruction. Journal of Education and Practice, 7(21), 144-148.

Tisngati, U. (2015). Proses berpikir reflektif mahasiswa dalam pemecahan masalah pada Materi himpunan ditinjau dari gaya kognitif Berdasarkan langkah polya. Beta: Jurnal Tadris Matematika, 8(2), 115-124.

Utami, A. D. (2016). Tipe kesalahan mahasiswa dalam menyelesaikan soal-soal geometri berdasar newman's error analysis (NEA). JIPM (Jurnal Ilmiah Pendidikan Matematika), 4(2), 85-92.

Widyastuti, R. (2015). Proses berpikir siswa dalam menyelesaikan masalah matematika berdasarkan teori Polya ditinjau dari adversity quotient tipe climber. Al-Jabar: Jurnal Pendidikan Matematika, 6(2), 183-194.

Yohanes, R. S. (2016). Upaya Meningkatkan Kemampuan Pemecahan Masalah Matematika Tim Olimpiade Matematika SMP Negeri o1 Madiun dengan Menggunakan Model Pemecahan Masalah Polya. In Seminar Nasional Matematika dan Pendidikan Matematika UNY (pp. 143-150). 